\title{
Public Support of Exclusive Breastfeeding in Women Workers
}

\author{
Luluk Rosida $^{1 *}$, Intan Mutiara Putri ${ }^{1}$, Dewi Kurniasari ${ }^{1}$ \\ ${ }^{1}$ Faculty of Health Science, Universitas Aisyiyah Yogyakarta, Yogyakarta, Indonesia \\ *Corresponding author. Email: rosidalulu@gmail.com
}

\begin{abstract}
Working women have their own dilemma because besides working women also have to continue performing their duties and responsibilities as mothers, one of which is to keep on providing exclusive breastfeeding. Public Support or work environment support is one of the determining factors for the success of exclusive breastfeeding for working mothers, in addition this is because the Government and many companies in Indonesia have not provided full leave allowance but only for up to 3 months. Many companies do not provide a special time for their employees to breastfeed or express milk at their workplaces, flexibility in working time, and duration of leave affect the success of exclusive breastfeeding. Besides providing space and tools three times better influence in supporting exclusive breastfeeding. The Government has regulated Public Support in Government Regulation No.33 of 2012 paragraph (2) concerning provisions regarding private breastfeeding program support at work carried out in accordance with company regulations between employers and workers/laborers, or through a join work agreement between trade unions/unions labourer with the businessman. In paragraph (3), the management of the workplace is explained and, the organizer of the public facilities must provide special facilities for breastfeeding and/or milking in accordance with the conditions of the company's capabilities. The purpose of this study is to look at how public support for the success of exclusive breastfeeding for working mothers, especially in Yogyakarta City Government. The results of the study show that public support is highly related to the success of exclusive breastfeeding.

Keywords: women workers, exclusive breastfeeding, public support
\end{abstract}

\section{INTRODUCTION}

Based on the results of the National Labour Force Survey (Sakernas), in 2016, the Labour Force Participation Rate (TPAK) recorded 2.1 million people or $72.2 \%$ and women who worked as many as $57-67 \%$. Thus, many women became career women (Agency Statistics Centre, 2016). Working women have their own dilemma because besides working women also have to continue performing their duties and responsibilities as a mother, one of which is to keep providing exclusive breastfeeding. The Government has regulated on Public Support in Government Regulation No.33 of 2012 concerning provisions regarding exclusive breastfeeding program support at work carried out in accordance with company regulations between employers and workers / laborers or through a join work agreement between trade unions/unions labourer with the businessman. The management of the workplace is explained and, the organizer of the public facilities must provide special facilities for breastfeeding and milking in accordance with the conditions of the company's capabilities.

ASI (Mother's Milk) is the first, main, and best food for natural babies. WHO or UNICEF has recommended the Global Strategy for Infant and Young Child Feeding, which are four essential things in infant and child feeding, one of which is breastfeeding only to infants up to 6 months of age, or called exclusive. Based on Government Regulation
Number 33 of 2012, Exclusive Breast Milk is breast milk that is given to babies from birth until 6 (six) months, without adding and / or replacing with other food or drinks (except drugs, vitamins, and minerals) [1]. Breastfeeding plays an important role in improving the quality of human resources at the beginning of its growth, because breast milk contains various nutrients needed generally for babies' growth and specifically for the development of various organs, besides breast milk contains antibodies that can protect babies against disease and death due to infectious diseases commonly occurring in the first year of life [2]. According to IDAI (Indonesian Paediatrician Association) exclusive breastfeeding is very important for babies' health, so for female workers still have to give milk to their babies because of its many benefits, if possible the baby can be taken to the place where the mother works, if the workplace is close to home, the mother can go home to feed the baby at rest or ask someone to help bring the baby to work. If the workplace is far from home, the mother can still breastfeed her baby with breast milk. The working mothers before going to work are milking and sending to babysitters to be given to babies [3].

\section{METHOD}

The research design used was an analytical research method using a retrospective approach. The independent variable in this study uses the independent variable work environment support, and the dependent variable is the success variable 
most accessible (accidental) way. The sampling technique uses a purposive sampling technique or sampling technique based on certain considerations according to inclusion criteria. Samples taken are breastfeeding mothers who meet the criteria of female workers, are bound and leave their babies $>6$ hours a day and live at home with their babies. While the exclusion criteria in this study are mothers with diseases, such as mastitis, heat, and so on. Mothers who have sick babies are not exclusively breastfed. The tool used for data collection to determine the success of exclusive breastfeeding in working mothers is to use a questionnaire that has been tested valid and reliability Data Analysis using univariate analysis and bivariate analysis using Chi-Square

\section{RESULTS AND DISCUSSION}

From the results of the study obtained the characteristics of respondents based on age and education level calculation of the sample size of 90 respondents. The technique used in sampling uses a convenience sampling technique that is sampling from the target population in the

Table 1 Frequency Distribution of Respondent Characteristics

\begin{tabular}{|c|c|c|c|c|c|}
\hline \multirow[b]{2}{*}{ No } & \multirow[b]{2}{*}{ Characteristics } & \multicolumn{2}{|c|}{ Exclusive Breast feeding } & \multicolumn{2}{|c|}{ Non-Exclusive Breast feeding } \\
\hline & & $\begin{array}{l}\text { Total } \\
\mathbf{N}=\mathbf{4 0}\end{array}$ & Percentage (\%) & $\begin{array}{l}\text { Total } \\
\mathbf{N}=\mathbf{5 0}\end{array}$ & Percentage (\%) \\
\hline 1 & Age & & & & \\
\hline \multirow{5}{*}{2} & $20-35$ years & 37 & 92,5 & 40 & 80 \\
\hline & $>35$ years & 3 & 7,5 & 10 & 20 \\
\hline & Level of education & & & & \\
\hline & High & 38 & 95 & 49 & 98 \\
\hline & Low & 2 & 5 & 1 & 2 \\
\hline
\end{tabular}

Based on Table 1, the frequency distribution of the characteristics of respondents who managed to give exclusive breastfeeding from 40 people who managed to know that the large number of respondents who succeeded in giving exclusive breastfeeding in the reproductive age range of 20-35 years were 37 people $(92.5 \%)$. The level of education of working mothers who succeeded in giving exclusive breastfeeding, in general, is a high level of education in which of the 40 respondents, there are 38 people $(95 \%)$ who have higher education. Frequency distribution of the characteristics of respondents who did not succeed in giving exclusive breastfeeding from 50 respondents found that the majority of respondents in the reproductive age range is $20-35$ years as many as 40 people $(80 \%)$.

The education level of working mothers who fail to provide exclusive breastfeeding is generally a high level of education where out of 50 respondents, there are 49 people $(98 \%)$ who have higher education. The results of the study found that of the 90 respondents who received exclusive breastfeeding less than $50 \%$ or only 40 people $(44.4 \%)$ of
90 respondents meant that not fully working mothers gave exclusive breastfeeding. The results of the distribution of statement frequency in the failure of exclusive breastfeeding in working mothers because the mother had given water with a spoon/bottle of $64.44 \%$ and gave formula milk $66.7 \%$ to the baby before the age of 6 months. [4]This is the same as Rizkianti [4], with the title analysis of the success factors of the practice of exclusive breastfeeding in the workplace which shows that many informants who fail exclusive breastfeeding say the giving prelacteal such as formula milk, and MP-ASI (weaning food) are only intended to help the baby get full quickly. They also claimed that because they were busy working, giving prelactealand MP-ASI was very useful when they were not at home. They feel that the quantity of milk that comes out is also small, so they worry that it won't make the child full. However, the actual treatment itself is not able to replace the function of colostrum, which is only found in breast milk. Breast milk has colostrum or yellow liquid, which contains immune substances that are known to be very good at protecting the baby's immune system. 
Table 2 Frequency Distribution of the Work Environment Support Questionnaire with the Success of Exclusive breastfeeding in Working Mothers

\begin{tabular}{|c|c|c|c|c|}
\hline $\begin{array}{c}\text { Public } \\
\text { support }\end{array}$ & No & & $\begin{array}{c}\mathbf{F} \\
(\mathrm{n}=90)\end{array}$ & $\%$ \\
\hline \multirow{6}{*}{$\begin{array}{l}\text { Superiors } \\
\text { support }\end{array}$} & 1. & The period of leave after childbirth & 87 & 96.67 \\
\hline & 2. & Asked to work according to previous work hours & 83 & 92,22 \\
\hline & 3. & Expressing milk during working hours & 83 & 92,22 \\
\hline & 4. & Service or work outside the city & 85 & 94,44 \\
\hline & 5. & Superiors support & 87 & 96.67 \\
\hline & 6. & Superiors give leeway in carrying out tasks or jobs & 78 & 86,67 \\
\hline $\begin{array}{l}\text { Colleagues } \\
\text { support }\end{array}$ & 7. & Colleagues support & 88 & 97,78 \\
\hline \multirow{5}{*}{$\begin{array}{l}\text { Supporting } \\
\text { breastfeeding } \\
\text { facilities and } \\
\text { infrastructure } \\
\text { in the } \\
\text { workplace }\end{array}$} & 8. & Understand how to save and use breast milk & 85 & 94,44 \\
\hline & 9. & Allowed to bring children & 30 & 33,33 \\
\hline & 10. & $\begin{array}{l}\text { Have a place to store breast milk such as refrigerators / } \\
\text { refrigerators }\end{array}$ & 63 & 79 \\
\hline & 11. & The period of leave after childbirth & 20 & 22,22 \\
\hline & 12. & Asked to work according to previous work hours & 62 & 68,89 \\
\hline
\end{tabular}

Table 2 illustrates a work environment support questionnaire with the success of exclusive breastfeeding. The results obtained from the distribution in 3 aspects of work environment support consisting of 12 statements were found highest in the answers of co-workers' statements supporting the exclusive breastfeeding program, which was 88 respondents $(97.78 \%)$. The lowest answer results in a statement at work ever held an extension about exclusive breastfeeding, namely 20 respondents $(22.22 \%)$.

Table 3 The correlation between public support and the success of exclusive breastfeeding in working mothers

\begin{tabular}{|c|c|c|c|c|c|c|c|c|}
\hline \multirow{2}{*}{$\begin{array}{l}\text { Public } \\
\text { support }\end{array}$} & \multicolumn{2}{|c|}{$\begin{array}{l}\text { Exclusive breast } \\
\text { feeding }\end{array}$} & \multicolumn{2}{|c|}{$\begin{array}{l}\text { Non-Exclusive } \\
\text { breast feeding }\end{array}$} & \multicolumn{2}{|c|}{ Total } & \multirow[t]{2}{*}{$\boldsymbol{P}$} & \multirow[t]{2}{*}{ CI 95\% } \\
\hline & f & $\%$ & f & $\%$ & f & $\%$ & & \\
\hline Support & 27 & 67,5 & 23 & 46 & 50 & 55,6 & & \\
\hline Not support & 13 & 32,5 & 27 & 54 & 40 & 44,4 & 0,02 & 2,109 \\
\hline amount & 40 & 100 & 50 & 100 & 90 & 100 & & \\
\hline
\end{tabular}

The results of the presentation of table 3 show that the working mothers who succeeded in giving exclusive breastfeeding were the most mothers who received support from the work environment, and the mothers who did not succeed in giving exclusive breastfeeding did not receive the most support from the work environment. Statistical test results obtained p-value $<\alpha \quad(0.025<0.05)$ and $95 \%$ confidence level, it can be concluded that there is a significant correlation between work environment support and the success of exclusive breastfeeding in working mothers. The description of work environment support from the results of the study in the results of table 3 shows the number of working mothers who succeeded in providing exclusive breastfeeding who received higher support from the work environment are as many as 30 people $(75 \%)$, compared to the work environment that is not supporting, namely 10 people $(25 \%)$. Whereas the results of working mothers who failed to provide exclusive breastfeeding were supported by a work environment of 18 people $(36 \%)$, and a work environment that did not support 32 people $(64 \%)$. Workplace support is an external factor that can influence exclusive breastfeeding [5], [6]. The Indonesian government has provided support for working mothers so that they can continue to breastfeed their babies. This is supported by the enactment of Government Regulation No. 33/2012 concerning exclusive breastfeeding, which requires every company or workplace to provide space for nursing mothers who work so that they can continue to provide exclusive breastfeeding [7], [8].

In Oktora [9], states that the availability of breastfeeding rooms or breast-storage facilities in companies/institutions/ offices of breastfeeding rooms or breast-storage facilities for breastfeeding activities even if only an empty room containing chairs, closed windows and a sink, if all is not available then inhibits working mother to breastfeed. So, if the room is not available, mothers look for a clean, safe, and comfortable place to breastfeed. Every workplace that employs a mother should have a day-care centre, but if it is not possible, the workplace must provide facilities and have company regulations that allow workers to continue to provide exclusive breastfeeding for six months [9] [10].

\section{CONCLUSION}

The optimal public support starting from policies including co-workers and infrastructure enabling working mothers to succeed in providing exclusive breastfeeding. For companies and institutions where they work, it is hoped that they can advocate for the provision of facilities at work that are used by nursing mothers as a form of implementing government regulations on breastfeeding for working mothers. 
[4] A. dkk Rizkianti, "Analisis Faktor Keberhasilan Praktik Pemberian ASI Eksklusif Di Tempat Kerja Pada Buruh Industri Tekstil Di Jakarta," Buletin Penelitian Kesehatan, vol. 42 (4), pp. 237-248., 2014.

[5] K. J. Bahriyah, F. Monifa, P. dan Abdul, "Hubungan Pekerjaan Ibu Terhadap Pemberian ASI Eksklusif Pada Bayi," J. Endur., vol. 2 (2)., pp. 113118., 2017.

[6] T. Listyaningrum and V. Vidayant, "Tingkat Pengetahuan dan Motivasi Ibu Berhubungan dengan Pemberian ASI Eksklusif pada Ibu Bekerja," J. Ners Midwifery Indones., vol. 4, pp. 55-62, 2016.

[7] S. Rohan, H.H., Siyoto, Kesehatan Reproduksi. 2013.

[8] M. Ramadani and N. . Ella, "Dukungan Suami dalam Pemberian ASI Eksklusif di Wilayah Kerja Puskesmas Air Tawar Kota Padang, Sumatera Barat," J. Kesehat. Masy. Nas., vol. 4(6), pp. 269-274, 2013.

[9] R. Oktora, “Gambaran Pemberian ASI Eksklusif pada Ibu Bekerja di Desa Serua Indah, Jombang, Tangerang Selatan,” J. Kesehat. Masy. Nas., vol. 4(1)., pp. $30-40$.

[10] V. Priscilla and D. Novrianda, "Dukungan Suami Terhadap Pemberian ASI Eksklusif Di Wilayah Kerja Puskesmas Lubuk Kilangan Kota Padang Tahun 2011," Ners J. Keperawatan, vol. 10 (1), pp. 197-209, 2014.

[3]IDAI, Indonesia Menyusui. 2010. 